\title{
Morphophysiological responses and mechanisms of salt tolerance in four ornamental perennial species under tropical climate
}

\author{
Claudivan F. de Lacerda ${ }^{1}$, Emanuele V. de Oliveira ${ }^{1}$, Antonia L. R. Neves ${ }^{1}$, Hans R. Gheyi ${ }^{2}$, \\ Marlos A. Bezerra ${ }^{3} \&$ Carlos A. G. Costa ${ }^{1}$ \\ ${ }^{1}$ Universidade Federal do Ceará/Departamento de Engenharia Agrícola. Fortaleza, CE, Brasil. E-mail: cfeitosa@ufc.br (Corresponding author) - ORCID: \\ 0000-0002-5324-8195; emanuellevictor@yahoo.com.br - ORCID: 0000-0003-0759-8837; leilaneves7@hotmail.com - ORCID: 0000-0002-0434-3321; \\ costacag@gmail.com - ORCID: 0000-0002-3191-8581 \\ ${ }^{2}$ Universidade Federal de Campina Grande/Departamento de Engenharia Agrícola. Campina Grande, PB, Brasil. E-mail: hgheyi@gmail.com - ORCID: \\ 0000-0002-7689-9628 \\ ${ }^{3}$ Embrapa Agroindústria Tropical. Fortaleza, CE, Brasil. E-mail: marlos.bezerra@embrapa.br - ORCID: 0000-0002-8622-0770
}

\begin{abstract}
Salinity affects growth and quality of ornamental plants, but studies on mechanisms of salt tolerance in these plants are scarce, particularly under tropical climate conditions. Thus, the morphophysiological leaf responses of four tropical ornamental species were studied, in order to identify the mechanisms involved in the tolerance to salinity and their potentials to be irrigated with brackish water. The research was conducted in a greenhouse using a completely randomized block design, in a $10 \times 4$ factorial scheme, with four repetitions. The treatments consisted of ten levels of electrical conductivity of irrigation water $(0.5 ; 1.0 ; 2.0 ; 3.0 ; 4.0 ; 5.0 ; 6.0 ; 8.0$; 10.0 and $12.0 \mathrm{dS} \mathrm{m}^{-1}$ ) and four ornamental tropical species (Catharanthus roseus, Allamanda cathartica, Ixora coccinea, and Duranta erecta). At 30 and 60 days after the beginning of saline treatments (DAST), measurements of leaf gas exchange and chlorophyll index were performed. At 60 DAST, leaf area, specific leaf area, leaf area ratio, leaf succulence, $\mathrm{Na}^{+}$and proline concentrations were measured. The physiological and morphophysiological responses of the leaves indicate that $I$. coccinea species has high capacity to grow under irrigation with saline water. Its higher tolerance to salinity is related to the lower concentration of $\mathrm{Na}^{+}$in the leaves. Conversely, the sensitivity of $D$. erecta was associated with high $\mathrm{Na}^{+}$and proline concentrations in leaves. The leaf concentration of proline showed to be an indicator more related to the sensitivity of ornamental plants to salt stress; however this relationship should not be generalized for all ornamental species studied.
\end{abstract}

Key words: salt stress, photosynthesis, leaf traits, sodium, proline

\section{Respostas morfofisiológicas e mecanismos de tolerância à salinidade em quatro espécies ornamentais perenes sob clima tropical}

RESUMO: A salinidade afeta o crescimento e a qualidade das plantas ornamentais, mas estudos sobre mecanismos de tolerância ao sal nessas plantas são escassos, particularmente sob condições de clima tropical. Assim, estudaramse as respostas morfofisiológicas foliares de quatro espécies ornamentais tropicais, a fim de identificar mecanismos envolvidos na tolerância à salinidade e seus potenciais para serem irrigadas com água salobra. A pesquisa foi conduzida em casa-de-vegetação, em delineamento em blocos casualizados, com tratamentos arranjados em esquema fatorial $10 \times 4$, com quatro repetições. Os tratamentos consistiram de 10 níveis de condutividades elétricas da água de irrigação $\left(0,5 ; 1,0 ; 2,0 ; 3,0 ; 4,0 ; 5,0 ; 6,0 ; 8,0 ; 10,0\right.$ e 12,0 dS m$\left.~^{-1}\right)$ e quatro espécies ornamentais tropicais (Catharanthus roseus, Allamanda cathartica, Ixora coccinea e Duranta erecta). Aos 30 e 60 dias após o início dos tratamentos salinos (DAST), foram avaliadas as trocas gasosas foliares e o índice relativo de clorofila. Aos 60 DAST foram mensurados: área foliar, área foliar específica, razão de área foliar, grau de suculência, e teores de $\mathrm{Na}^{+}$e de prolina. A análise das respostas fisiológicas e morfofisiológicas foliares indica que I. coccinea apresenta alta capacidade de crescimento sob irrigação com água salina. Sua maior tolerância à salinidade está relacionada à menor concentração foliar de $\mathrm{Na}^{+}$. Por outro lado, a sensibilidade de D. erecta foi associada a elevadas concentrações de $\mathrm{Na}^{+}$e prolina nas folhas. A concentração de prolina se mostrou um indicador mais relacionado à sensibilidade ao estresse salino, porém essa relação não pode ser generalizada para todas as espécies ornamentais estudadas.

Palavras-chave: estresse salino, fotossíntese, traços foliares, sódio, prolina 


\section{INTRODUCTION}

The worth of the world production of ornamental plants and cut flowers is about 50 billion Euros, corresponding to a high global consumption annually. However, currently, there is a reduction in this production partially due to the problems related to abiotic stresses, such as salinity (Cassaniti et al., 2013; García-Caparrós et al., 2016).

In Brazil, the cultivation of ornamental plants is an important economic activity due to the climatic diversity (wet, semi-arid, hot, cold) and strategic points for their marketing. The Brazilian floriculture has shown progressive development, due to the increase in the internal market and the conquest in exports, which has contributed to keeping local workers employed in rural areas.

High salinity compromises the development of crops, especially in dry climates (Munns \& Tester, 2008). Salinity affects water absorption, physiological processes and plant growth (Lacerda et al., 2006a; Acosta-Motos et al., 2015; Taiz et al., 2015). For ornamental plants, salt stress can also affect the visual quality, a relevant characteristic in the commercialization (Niu et al., 2012; Neves et al., 2018; Oliveira et al., 2018).

Irrigation with saline water can be an important strategy for the cultivation of species used in landscaping. However, it is necessary to find ornamental species which can be established under salt stress conditions (Miyamoto et al., 2004; Niu et al., 2007; Cai et al., 2014; Wu et al., 2016; Liu et al., 2017; Oliveira et al., 2017). However, studies on mechanisms of salt tolerance in ornamental plants are scarce, particularly under tropical climate.

In this context, in this study it was aimed to evaluate the effects of salt stress intensity on the physiological and morphological responses of four ornamental perennial species, in order to identify the mechanisms involved in the salt tolerance and identify species with potential to be irrigated with saline waters under tropical climate.

\section{Material ANd Methods}

The study was conducted in a greenhouse, belonging to the Departamento de Engenharia Agrícola of the Universidade Federal do Ceará, in Fortaleza, CE, Brazil, located at the geographical coordinates: $3^{\circ} 45^{\prime} \mathrm{S}$; $38^{\circ} 33^{\prime} \mathrm{W}$ and approximately $19 \mathrm{~m}$ of altitude. The climate in the region is Aw', tropical rainy, according to Köppen's classification (Alvares et al., 2013). The mean air temperature inside the greenhouse ranged from 29.1 to $31.3{ }^{\circ} \mathrm{C}$, while the air relative humidity oscillated from 57.8 to $70.2 \%$. The photoperiod was about $12 \mathrm{~h}$ (Oliveira et al., 2018).

A completely randomized block design was used in a 10 $\mathrm{x} 4$ factorial scheme, relative to 10 salt concentrations of the irrigation water and four ornamental perennial species. Four blocks were used, totaling 160 experimental units formed by two pots, each containing one plant.

The irrigation water electrical conductivities (ECw) for the experiment were $0.5,1.0,2.0,3.0,4.0,5.0,6.0,8.0,10.0$ and $12.0 \mathrm{dS} \mathrm{m}^{-1}$, obtained by dissolving sodium chloride $(\mathrm{NaCl})$ and calcium chloride $\left(\mathrm{CaCl}_{2} \cdot 2 \mathrm{H}_{2} \mathrm{O}\right)$, in equivalent proportion of 7:3, in water from a well $\left(\mathrm{ECw}=0.9 \mathrm{dS} \mathrm{m}^{-1}\right)$ situated in the experimental area. To obtain the lowest level of salinity, well water was diluted in rainwater. The proportion of salts used in irrigation water is a representative approximation for mono and divalent cations of most sources of water available for irrigation in Northeastern Brazil (Medeiros, 1992).

Seedlings of four perennial ornamental species were used: Catharanthus roseus (L) G. Don., Allamanda cathartica L., Ixora coccinea L. and Duranta erecta L. These species are classified as shrubs or semi herbaceous and are often found in gardens and landscapes in tropical regions. The seedlings with 30 days of germination were obtained from a certified producer registered at the Ministry of Agriculture, Livestock and Supply, Brazil.

The seedlings were transplanted to 7 -L plastic pots with holes at the bottom to drain any excess water. The pots were filled with a 2- to 3-mm-thick layer of crushed stone at the bottom to facilitate drainage, and the remaining volume with the substrate composed of a mixture of sand material, earthworm humus and Ultisol, in a proportion of 7:1:2 (v/v/v), respectively, and it was characterized as non-saline and nonsodic. After transplanting, the seedlings were irrigated using well water for a period of 15 days. After this period the plants were irrigated with the waters of different salt concentrations according to the treatments.

The applied water depth followed the principle of drainage lysimeter, trying to maintain the soil at field capacity and applying a leaching fraction of 0.15 , to avoid excessive accumulation of soluble salts in the soil (Ayers \& Westcot, 1999). Irrigations were performed every other day, and the irrigation depth for each treatment was manually applied in a localized manner.

At 30 and 60 DAST, readings of leaf gas exchanges and relative chlorophyll index were taken. At 60 DAST, plants were harvested, and the following parameters were determined: leaf area $\left(\mathrm{LA}, \mathrm{m}^{2}\right.$ plant ${ }^{-1}$ ), leaf area ratio (LAR, $\left.\mathrm{cm}^{2} \mathrm{~g}^{-1}\right)$, specific leaf area (SLA, $\mathrm{cm}^{2} \mathrm{~g}^{-1}$ ), leaf succulence (LS, $\mathrm{g} \mathrm{H}_{2} \mathrm{O} \mathrm{cm}^{-2}$ ) and leaf concentration of $\mathrm{Na}^{+}$(flame photometer) and proline. Leaf traits, $\mathrm{Na}^{+}$, and proline concentration were determined according to Benincasa (2003), Malavolta et al. (1997) and Bates et al. (1973), respectively.

Measurements of the rates of photosynthesis (A), transpiration (E), stomatal conductance (gs) and internal $\mathrm{CO}_{2}$ concentration $(\mathrm{Ci})$ were taken in fully expanded leaves in good phytosanitary condition, using an infrared gas analyzer (Model Li - 6400XT - LICOR", USA). Evaluations were carried out between 8 and $11 \mathrm{~h}$, using saturating radiation $(1,500$ $\left.\mu \mathrm{mol} \mathrm{m} \mathrm{m}^{-2} \mathrm{~s}^{-1}\right), \mathrm{CO}_{2}$ concentration of $400 \mathrm{~mol} \mathrm{~mol}^{-1}$, and under environmental conditions of air temperature and air relative humidity. Relative chlorophyll index was obtained using a portable chlorophyll meter (SPAD 502, Minolta Co. Ltd, Osaka, Japan), in the same leaves used for the analyses of leaf gas exchanges.

The results were subjected to analysis of variance (F test) and polynomial regression analysis to check the existence of individual effects and interactions between factors, using as a support tool the statistical software Sisvar (Ferreira, 2011). For leaf gas exchanges and relative chlorophyll index, the statistical 
analysis was performed separately for each period, and the data were also presented separately.

\section{Results AND Discussion}

Figure 1 presents the results of stomatal conductance (gs), net photosynthesis $(\mathrm{A})$ and transpiration $(\mathrm{E})$, in response to irrigation water salinity, at 30 and 60 DAST. It can be observed that the species $C$. roseus stands out with highest values of gs (Figures $1 \mathrm{~A}$ and B), A (Figures $1 \mathrm{C}$ and $\mathrm{D}$ ) and $\mathrm{E}$ (Figures $1 \mathrm{E}$ and F) under low-salinity conditions, whereas the species $I$. coccinea showed the lowest values under these same conditions.

When comparing the effects of salinity on leaf gas exchanges, it becomes evident that at 30 DAST the species I. coccinea was little influenced by the stress, while the rates observed for D. erecta were close to zero at the highest levels of salinity (Figures 1A, C and E). At the highest level of salinity, the photosynthetic rate decreased by $67.8,60.6,22.5$ and $88.4 \%$ at 30 DAST (Figure 1C), respectively for species C. roseus, $A$. cathartica, I. coccinea and D. erecta. At 60 DAST (Figure 1D), these reductions were intensified, reaching 100, 90.3, 51.4 and $100 \%$, respectively. The percentage reductions in gs (Figure 1B) and $\mathrm{E}$ (Figure $1 \mathrm{~F}$ ) also increased with the prolongation of stress period and were similar to those of $\mathrm{A}$, being more intense in D. erecta and less in I. coccinea.

The internal $\mathrm{CO}_{2}$ concentration (Figures $2 \mathrm{~A}$ and $\mathrm{B}$ ) and the instantaneous carboxylation efficiency (Figures 2C and D) decreased linearly for all species, but with marked differences between them, especially at 60 DAST measurements. In the determination performed at 30 DAST the species I. coccinea stood out in relation to the others, showing only small reduction in the Ci value. At 60 DAST, this species continued to show a smaller decrease in the $\mathrm{A} / \mathrm{Ci}$ ratio, despite the high reduction in $\mathrm{Ci}$. At this period, the species $A$. cathartica showed the largest reduction in the $\mathrm{Ci}$, while the species $C$. roseus and $D$. erecta had the greatest reductions in the $\mathrm{A} / \mathrm{Ci}$ ratio.

The relative chlorophyll index (Figure 3 ) showed a trend similar to that of most of the variables analyzed, with a reduction as salinity increased for all species studied. The negative effects became more intense with the increase in stress duration, and in the measurement at 60 DAST decreases of $77.7,26.0,24.0$ and $33.5 \%$ were observed in the species $C$. roseus, $A$. cathartica, $I$. coccinea and $D$. erecta, respectively, at the highest level of irrigation water salinity $\left(\mathrm{ECw}=12 \mathrm{dS} \mathrm{m}^{-1}\right)$ compared to the control treatment (Figure 3).

The data of leaf gas exchanges (Figures 1 and 2) and chlorophyll index (Figure 3) demonstrate clearly the intensification of the negative effects with the duration of exposure to salinity, a common response for plants subjected to this type of abiotic stress (Bacha et al., 2017). The proportional reductions in $g s$ and $A$ caused by salinity (Figure 1 ) indicate that the decrease in the photosynthetic rate may be related to stomatal effects, which limit the $\mathrm{CO}_{2}$ influx for the assimilation process.

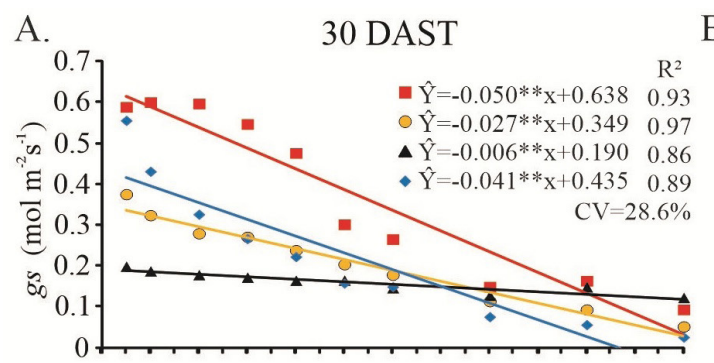

B.
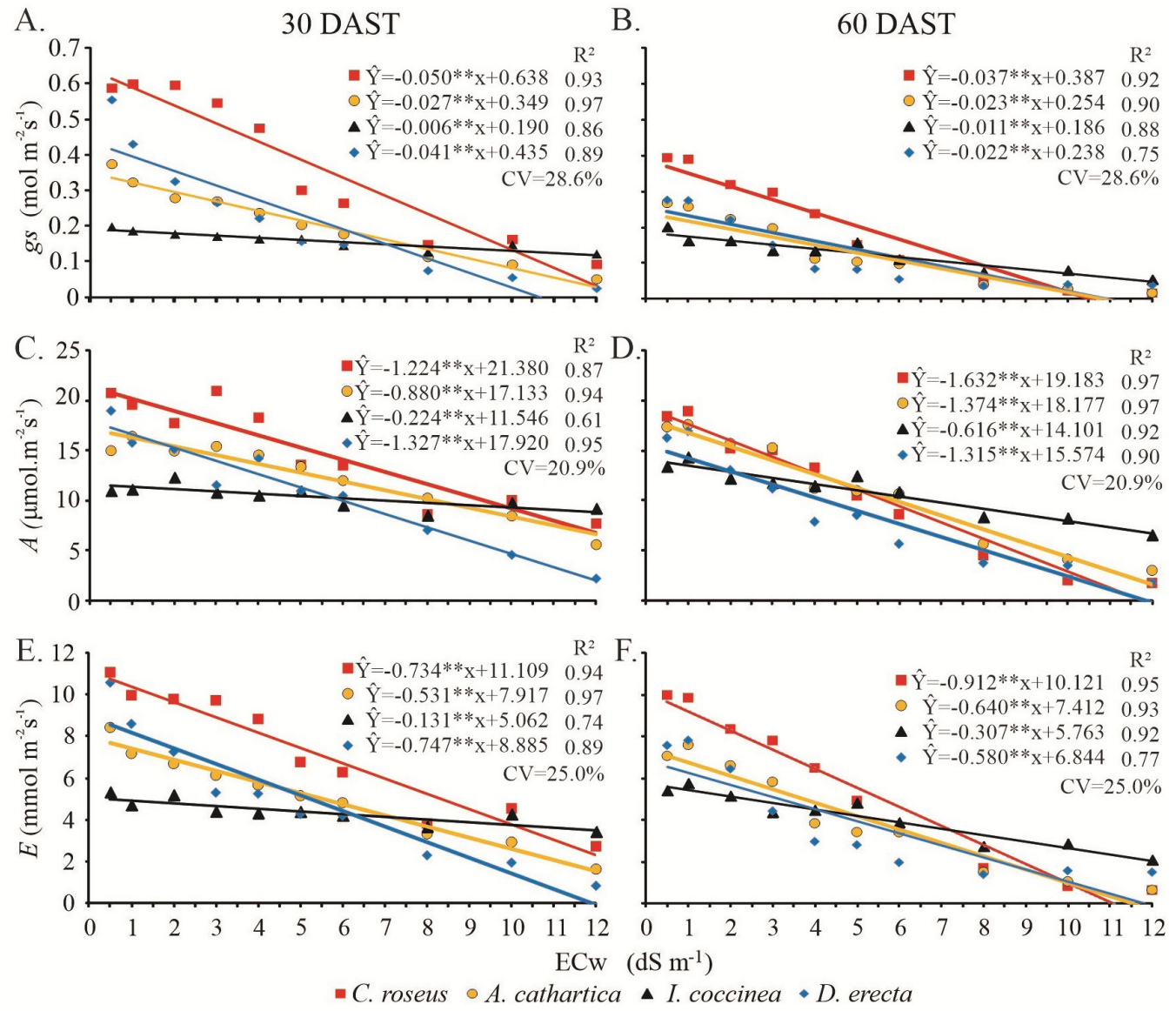

*,** - Significant at $\mathrm{p} \leq 0.05$ and $\mathrm{p} \leq 0.01$ by $\mathrm{F}$ test, respectively; $\mathrm{CV}$ - Coefficient of variation

Figure 1. Stomatal conductance (gs), net photosynthesis rate (A) and transpiration rate (E) in leaves of C. roseus, A. cathartica, I. coccinea and D. erecta, at $30(\mathrm{~A}, \mathrm{C}$ and $\mathrm{E})$ and $60(\mathrm{~B}, \mathrm{D}$ and $\mathrm{F})$ days after the beginning of saline treatments (DAST) as a function of electrical conductivity of irrigation water $(\mathrm{ECw})$ 


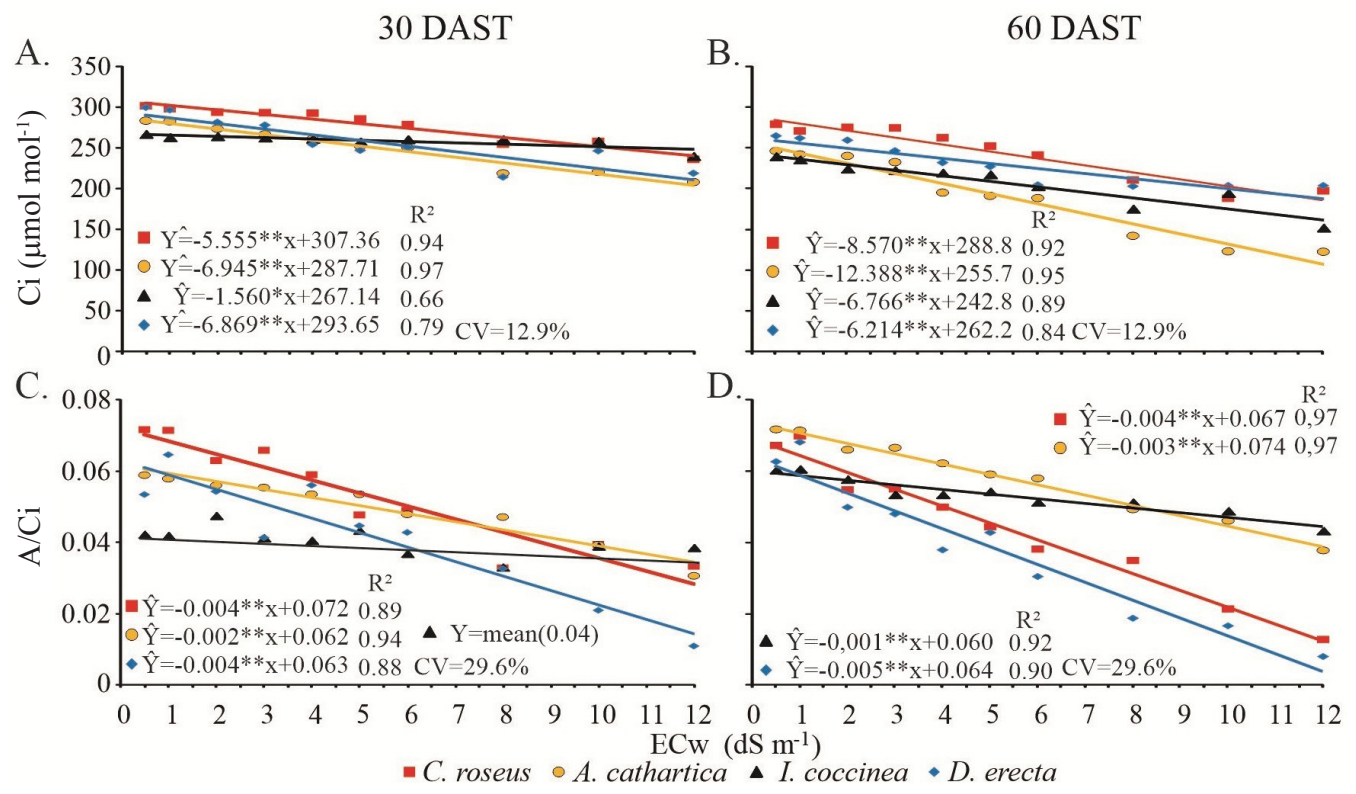

*, ** - Significant at $\mathrm{p} \leq 0.05$ and $\mathrm{p} \leq 0.01$ by $\mathrm{F}$ test, respectively; $\mathrm{CV}$ - Coefficient of variation

Figure 2. Internal $\mathrm{CO}_{2}$ concentration $(\mathrm{Ci})$ and instantaneous carboxylation efficiency (A/Ci ratio) in leaves of $C$. roseus, $A$. cathartica, I. coccinea and D. erecta, at 30 (A and C) and 60 (B and D) days after the beginning of saline treatments (DAST) as a function of electrical conductivity of irrigation water $(\mathrm{ECw})$

A.

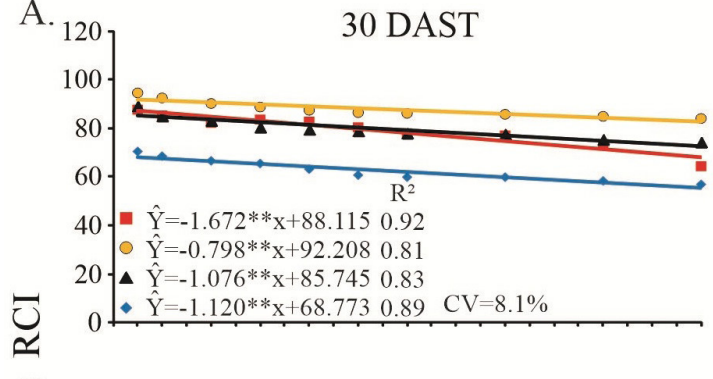

B.

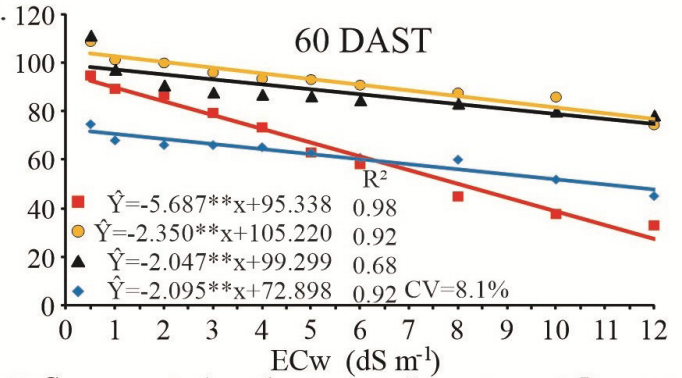

- C. roseus $\circ$ A. cathartica $\triangle I$ coccinea - D. erecta

*, ** - Significant at $\mathrm{p} \leq 0.05$ and $\mathrm{p} \leq 0.01$ by F test, respectively; CV - Coefficient of variation

Figure 3. Relative chlorophyll index (RCI) in leaves of C. roseus, A. cathartica, $I$. coccinea and $D$. erecta in evaluations carried out at 30 (A) and 60 (B) days after the beginning of saline treatments (DAST) as a function of electrical conductivity of irrigation water $(\mathrm{ECw})$

On the other hand, data of $\mathrm{Ci}$ (Figures $2 \mathrm{~A}$ and $\mathrm{B}$ ) and $\mathrm{A} / \mathrm{Ci}$ (Figures 2C and $\mathrm{D}$ ) indicate that non-stomatal responses may also have acted in this inhibition, particularly in the longer duration of exposure to stress. In the last evaluation (60 DAST), the reductions in $\mathrm{Ci}$ were lower in the species that had greater inhibition in the photosynthetic rate, C. roseus and D. erecta (mean reduction of $31.1 \%$ for $\mathrm{Ci}$ ), compared to the other two species, A. cathartica and I. coccinea (mean reduction of $44.7 \%$ for $\mathrm{Ci}$ ). Consequently, great difference in the reduction of instantaneous carboxylation efficiency was observed, reaching a mean reduction of $82.1 \%$ in the two former species and only $33.5 \%$ in the latter species.

It was observed that the species $I$. coccinea stands out for exhibiting the lowest and highest rates of photosynthesis (Figure 1B), respectively under conditions of low and high salinity. On the other hand, species $D$. erecta and C. roseus showed the greatest limitations under salt stress. For these species, it is evident that the reduction in the photosynthetic rate is associated with stomatal and non-stomatal effects, notably at the highest levels of salinity, as has been reported in other studies (Seemann \& Cristchley, 1985; Debez et al., 2008; Bacha et al., 2017).

In plants subjected to severe level of salt stress, decrease in photosynthesis can be related to low stomatal conductance, reduction in chlorophyll concentration, and inhibition in photochemical and enzymatic processes related to $\mathrm{CO}_{2}$ assimilation (Rahnama et al., 2010; Silva et al., 2011; Taiz et al., 2015). In the long term, this may be the result, at least in part, of the accumulation of $\mathrm{Na}^{+}$and $\mathrm{Cl}^{-}$in the leaves, which reach toxic levels in the chloroplasts (Munns \& Tester, 2008; Álvarez et al., 2018).

Chlorophyll loss under salinity can be related to saltinduced activity of chlorophyllase, an enzyme that acts in the process of degradation of this molecule (Taiz et al., 2015), and reduction in chlorophyll concentration can reduce the commercial value of ornamental plants (Toscano et al., 2018). In this study, the chlorophyll index was severely affected in $C$. roseus (Figure 3 ), which was visually observed at 60 DAST, and this effect can explain, at least in part, the greater reduction in the photosynthesis rate in this species (Bacha et al., 2017; Li et al., 2018). On the other hand, chlorophyll index decreased linearly for other species, with little difference among them. This indicates that chlorophyll index should not always be used as an indicator to show differences in salt tolerance. For I. coccinea and D. erecta, for example, chlorophyll index 
decreases by 24.0 and $33.5 \%$ at the highest level of salinity, while inhibitions in the photosynthetic rate reach 51.4 and $100 \%$, respectively.

Leaf growth was strongly affected by the increase in irrigation water salinity (Figure 4A), and the effects were less significant on $I$. coccinea. Leaf morphophysiological characteristics, SLA (Figure 4B), LAR (Figure 4C), and LS (Figure 4D), were also influenced by the increase in irrigation water salinity, with minimum effect being observed in leaves of $I$. coccinea. At the low levels of salinity, C. roseus plants exhibited the highest values of SLA and LAR and lowest values of LS. This species managed to maintain and even increase the values of SLA and LAR up to moderate levels of salinity, but the reduction became drastic at the higher levels, especially for LAR. The other species (A. cathartica and $D$. erecta) also showed reductions in SLA and LAR, which were less pronounced than in $C$. roseus.

Leaf succulence decreased linearly in the species D. erecta, but no mathematical model fitted to $C$. roseus and $I$. coccinea data (Figure $4 \mathrm{D}$ ). The species $A$. cathartica showed a quadratic response with reduction in leaf succulence up to intermediate levels of salinity and subsequent increase at the higher levels. This species also showed higher values at both low and high levels of water salinity, compared to the other species, whereas $C$. roseus and D. erecta were the ones that showed lowest leaf succulence at the highest level of salinity. When comparing the highest and lowest water salinity levels, the reduction in LS reached 49, 20, 18 and $60.7 \%$, respectively for C. roseus (based on mean values), A. cathartica, I. coccinea (based on mean values) and $D$. erecta.

The effects of salinity on leaf area (Figure 4A) were less significant on I. coccinea, a species that also showed lesser effects of salinity on the leaf gas exchanges (Figures 1 and 2).
Maintenance of a larger area intended for photosynthesis and higher photosynthetic rates per leaf area unit are two important indicators of salt tolerance (Munns \& Tester, 2008), which markedly distinguish the species I. coccinea from the others studied here.

Reduction in SLA caused by water salinity (Figure 4B) indicates an increase in leaf thickness, which may be due to the increment in cell wall thickening or to the increase in the volume of the spongy mesophyll cells, to the detriment of the volume of the palisade parenchyma cells (Costa et al., 2003). Although such increase in mesophyll thickness may favor the maintenance of net photosynthesis rate per leaf area unit under salt stress conditions (Lacerda et al., 2006a), this was not evident in the present study, since the maintenance of higher photosynthetic rates under high salinity (Figure 1B) occurred in the species $I$. coccinea, which had slight reduction in SLA (Figure 4B).

LAR indicates the size of the system to capture light for photosynthesis in relation to the total biomass of the plant, resulting from the product between SLA and leaf weight ratio. The results demonstrate that the reduction in LAR (Figures $4 \mathrm{C}$ ) in the species $C$. roseus, $A$. cathartica and D. erecta was largely due to the decrease in SLA. The species I. coccinea once again presented itself as the one with the most balanced response, with minimal variations in SLA, leaf weight ratio (data not shown) and LAR.

In many species, leaf succulence increases in response to salt stress, a mechanism of dilution of potentially toxic ions accumulated in the leaves (Costa et al., 2003; García-Caparrós et al., 2016; Lacerda et al., 2006a). However, reductions or lack of effects of salinity on leaf succulence have been observed in other species or cultivars (Costa et al., 2003; García-Caparrós et al., 2016), similar to the results obtained with the species evaluated in the present study (Figure 4D).
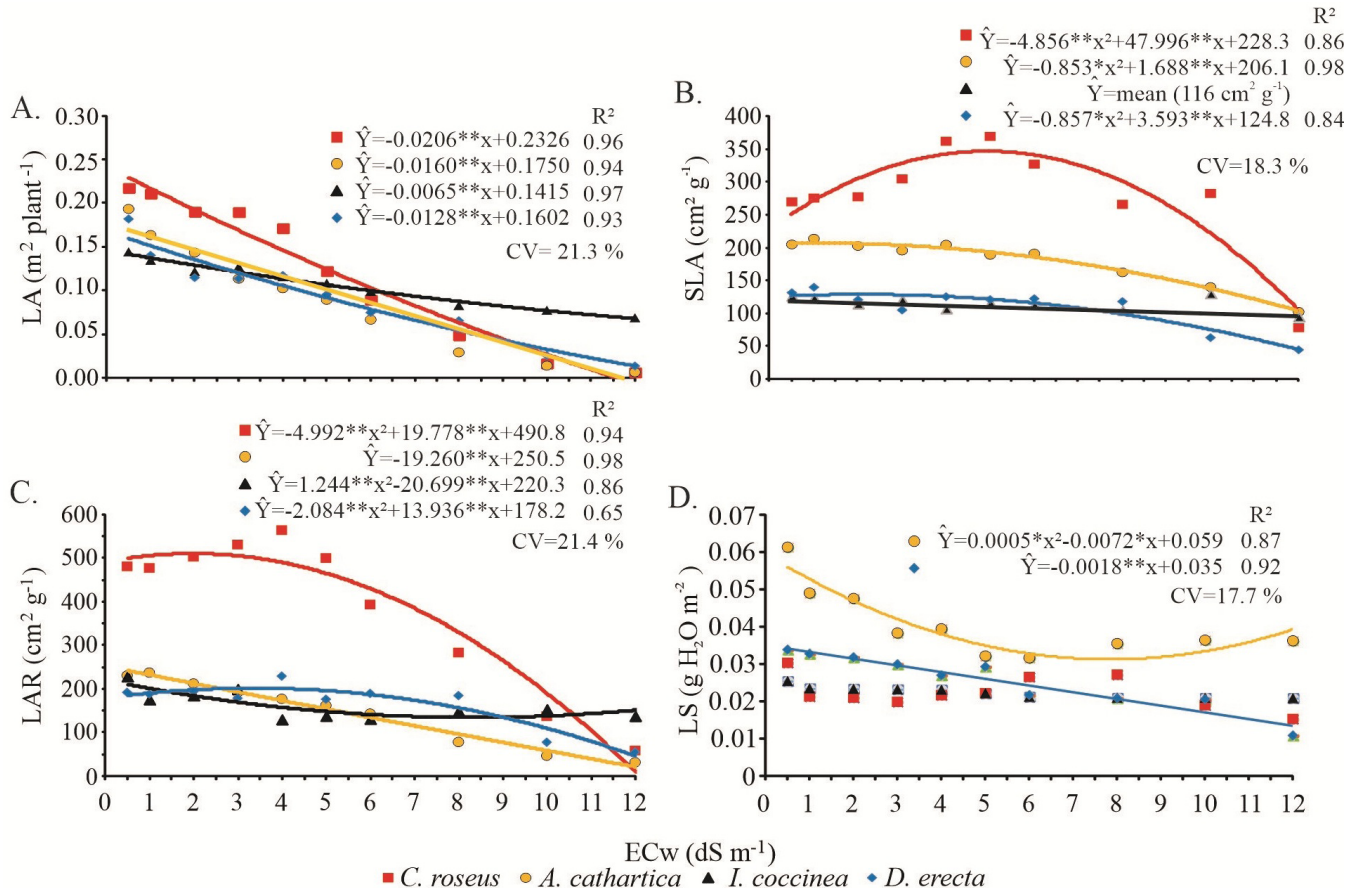

*, ** - Significant at $\mathrm{p} \leq 0.05$ and $\mathrm{p} \leq 0.01$ by $\mathrm{F}$ test, respectively; $\mathrm{CV}$ - Coefficient of variation

Figure 4. Leaf area - LA (A), specific leaf area - SLA (B), leaf area ratio - LAR (C) and leaf succulence - LS (D), in C. roseus, A. cathartica, I. coccinea and D. erecta plants at 60 days after the beginning of saline treatments (DAST) as a function of electrical conductivity of irrigation water (ECw) 

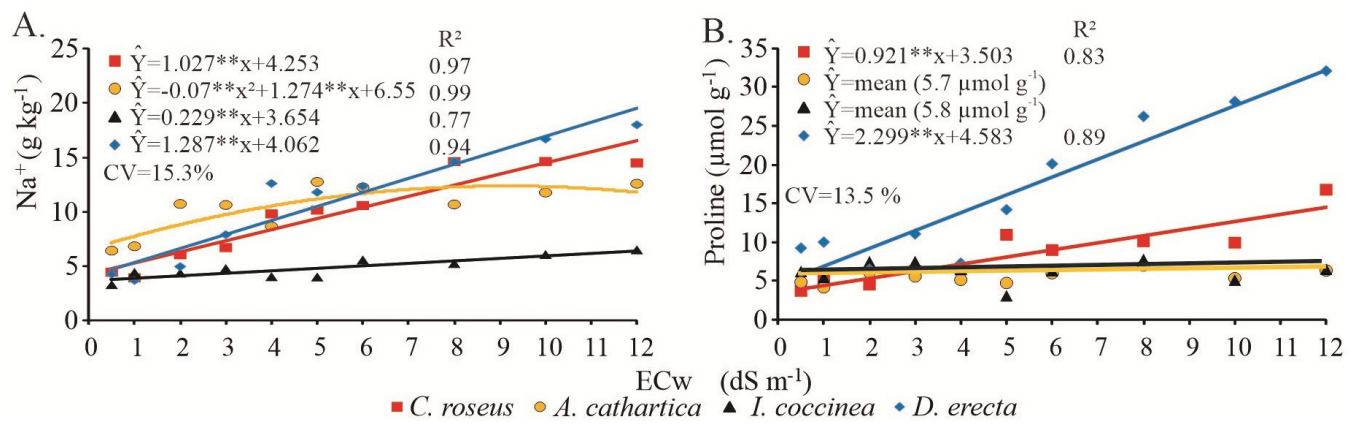

*,** - Significant at $\mathrm{p} \leq 0.05$ and $\mathrm{p} \leq 0.01$ by F test, respectively; $\mathrm{CV}$ - Coefficient of variation

Figure 5. Leaf concentration of $\mathrm{Na}^{+}$(A) and proline (B) in C. roseus, A. cathartica, I. coccinea and D. erecta plants at 60 days after the beginning of saline treatments (DAST) as a function of electrical conductivity of irrigation water (ECw)

Sodium concentration in leaves increased with the increment in the values of irrigation water salinity (Figure $5 \mathrm{~A}$ ). However, this increase varied among the species at different levels of salinity. The species $A$. cathartica had the highest $\mathrm{Na}^{+}$ concentration at the lowest level of salinity, showing an increase up to the intermediate level $\left(6 \mathrm{dS} \mathrm{m}^{-1}\right)$ with a subsequent trend to stabilization. The other species showed linear increases in the leaf sodium concentration, with increments of 1.027, 0.229 and $1.287 \mathrm{~g} \mathrm{~kg}^{-1}$ per unit increase in the electrical conductivity of the irrigation water, respectively for C. roseus, I. coccinea and D. erecta.

Leaf proline concentration did not show any definite trend with the increase in water salinity in the species $A$. cathartica and $I$. coccinea (Figure $5 \mathrm{~B}$ ). On the other hand, there were linear increases in proline concentration for $C$. roseus and $D$. erecta, with increments of 0.921 and $2.299 \mu \mathrm{mol} \mathrm{g}{ }^{-1}$ per unit increase in the electrical conductivity, respectively.

Differential salt tolerance can be related to lower accumulation of potentially toxic ions, like sodium, or high accumulation of compatible solutes, like proline. These results showed that the greatest increments in $\mathrm{Na}^{+}$contents occurred in $D$. erecta and C. roseus, and the smallest ones in the species I. coccinea (Figure 5A). Based on these results it is clear that the best indicators of salt tolerance observed for I. coccinea, i.e., maintenance of leaf gas exchanges, chlorophyll index, and leaf morphological characteristics, can be explained mostly by the capacity to maintain low concentrations of $\mathrm{Na}^{+}$in photosynthesizing tissues, as also found by other authors in different species (Muuns \& Tester, 2008; Cassaniti et al., 2009, 2013; Liu et al., 2017; García-Caparrós \& Lao, 2018). Intrinsic characteristics of this species, including low $\mathrm{E}$ (Figures $1 \mathrm{E}$ and F) and SLA (Figure 4B), may contribute to reduce the accumulation of potentially toxic ions in the leaves. On the other hand, the species that showed the highest accumulation of sodium in the leaves, D. erecta, was also the one that showed symptoms of leaf necrosis (results not presented) and reduction in leaf succulence.

Some authors have found positive correlation between proline accumulation and salt tolerance of plants (Kaur \& Asthir, 2015; García-Caparrós et al., 2016; García-Caparrós \& Lao, 2018; Li et al., 2018). Accumulation of proline could be due to synthesis, decreased degradation, lower utilization, or hydrolysis of proteins, and it contributes to stabilization of sub-cellular structures, scavenging free radicals, and buffering cellular redox potential (Kaur \& Asthir, 2015). However, these results demonstrate that proline contents increased linearly in the species $C$. roseus and $D$. erecta, being higher in the latter, but did not change in the species $I$. coccinea and A. cathartica (Figure 5B).

These results show the complexity of this type of response, and no correlation was observed between the increase in proline concentrations in the leaves and tolerance to salinity, since the species which showed the best physiological performance under salt stress did not exhibit any change in proline contents. Conversely, the highest increases were found in the species $C$. roseus and D. erecta, which showed greater reductions in the photosynthetic rates. In this case, proline appears to be an indicator of the damage caused by salt stress, as demonstrated by Lacerda et al. (2003) in sorghum genotypes.

On the other hand, the species A. cathartica, which also underwent a strong inhibition in physiological traits, showed no response in terms of proline concentrations (Figure 5B). A possible explanation would be the maintenance of high leaf succulence (Figure 4D) in this species, since the increase in proline concentration seems to depend on the degree of hydration of the tissues (Lacerda et al., 2006b). The results obtained with $D$. erecta are consistent with this hypothesis, since this species had greater reduction in leaf succulence and greater increase in proline concentrations.

\section{Conclusions}

1. The greater tolerance to salinity of $I$. coccinea, evidenced by the smallest reductions in the photosynthetic rate, is due to its ability to prevent excessive accumulation of sodium in photosynthesizing tissues and maintenance of the morphophysiological leaf traits.

2. Low values of stomatal conductance, transpiration rate, and specific leaf area, may contribute for plants of I. coccinea to tolerate the adverse conditions imposed by excess of salts in the root environment.

3. The leaf concentration of proline is the indicator most related to the sensitivity of ornamental plants to salt stress, since the highest accumulation was observed in the most salt sensitive species. However, this negative relationship should not be generalized for all ornamental species studied, since the accumulation of proline also depends on the degree of leaf succulence. 


\section{ACKNOWLEDGements}

Acknowledgments are due to Conselho Nacional de Desenvolvimento Científico e Tecnológico (CNPq), Instituo Nacional de Ciência e Tecnologia em Salinidade (INCTSal) and Coordenação de Aperfeiçoamento de Pessoal de Nível Superior (CAPES), Brazil, for the financial support to this research.

\section{Literature Cited}

Acosta-Motos, J. R.; Diaz-Vivancos, P.; Álvarez, S.; FernándezGarcía, N.; Sánchez-Blanco, M. J.; Hernández, J. A. NaClinduced physiological and biochemical adaptative mechanisms in the ornamental Myrtus communis L. plants. Journal of Plant Physiology, v.183, p.41-51, 2015. https://doi.org/10.1016/j. jplph.2015.05.005

Alvares, C. A.; Stape, J. L.; Sentelhas, P. C.; Gonçalves, J. L. M.; Sparovek, G. Köppen's climate classification map for Brazil. Meteorologische Zeitschrift, v.22, p.711-728, 2013. https://doi. org/10.1127/0941-2948/2013/0507

Álvarez, S.; Rodríguez, P.; Broetto, F.; Sánchez-Blanco, M. J. Long term responses and adaptive strategies of Pistacia lentiscus under moderate and severe deficit irrigation and salinity: Osmotic and elastic adjustment, growth, ion uptake and photosynthetic activity. Agricultural Water Management, v.202, p.253-262, 2018. https:// doi.org/10.1016/j.agwat.2018.01.006

Ayers, R. S.; Westcot, D. W. A qualidade de água na agricultura. 2.ed. Campina Grande: UFPB, 1999. 153p.

Bacha, H.; Tekaya, M.; Drine, S.; Guasmi, F.; Touil, L.; Enneb, H.; Triki, T.; Cheour, F.; Ferchichi, A. Impact of salt stress on morpho-physiological and biochemical parameters of Solanum lycopersicum cv. Microtom leaves. South African Journal of Botany, v.108, p.364-369, 2017. https://doi.org/10.1016/j.sajb.2016.08.018

Bates, L. S.; Waldren, R. P.; Teare, J. D. Rapid determination of free proline for water-stress studies. Plant and Soil, v.39, p.205-207, 1973. https://doi.org/10.1007/BF00018060

Benincasa, M. M. P. Análise de crescimento de plantas, noções básicas. 2.ed. Jaboticabal: FUNEP, 2003. 41p.

Cai, X.; Niu, G.; Starman, T.; Hall, C. Response of six garden roses (Rosa $\times$ hybrida L.) to salt stress. Scientia Horticulturae, v.168, p.27-32, 2014. https://doi.org/10.1016/j.scienta.2013.12.032

Cassaniti, C.; Romano, D.; Hop, M. E. C. M.; Flowers, T. J. Growing floricultural crops with brackish water. Environmental and Experimental Botany, v.92, p.165-175, 2013. https://doi. org/10.1016/j.envexpbot.2012.08.006

Cassaniti, C.; Leonardi, C.; Flowers, T. J. The effects of sodium chloride on ornamental shrubs. Scientia Horticulturae, v.122, p.586-593, 2009. https://doi.org/10.1016/j.scienta.2009.06.032

Costa, P. H. A.; Silva, J. V.; Bezerra, M. A.; Eneas Filho, J.; Prisco, J. T.; Gomes Filho, E. Crescimento e níveis de solutos orgânicos e inorgânicos em cultivares de Vigna unguiculata submetidos à salinidade. Revista Brasileira de Botânica, v.26, p.289-297, 2003. https://doi.org/10.1590/S0100-84042003000300002

Debez, A.; Koyroc, H.-W.; Grignond, C.; Abdellya, C.; Huchzermeyer, B. Relationship between the photosynthetic activity and the performance of Cakile maritime after long-term salt treatment. Physiologia Plantarum, v.133, p.373-385, 2008. https://doi. org/10.1111/j.1399-3054.2008.01086.x
Ferreira, D. F. Sisvar: A computer statistical analysis system. Ciência e Agrotecnologia, v.35, p.1039-1042, 2011. https://doi.org/10.1590/ S1413-70542011000600001

García-Caparrós, P.; Lao, M. T. The effects of salt stress on ornamental plants and integrative cultivation practices. Scientia Horticulturae, v.240, p.430-439, 2018. https://doi.org/10.1016/j. scienta.2018.06.022

García-Caparrós, P.; Llanderal, A.; Pestana, M.; Correia, P. J.; Lao, M. T. Tolerance mechanisms of three potted ornamental plants grown under moderate salinity. Scientia Horticulturae, v.201, p.84-91, 2016. https://doi.org/10.1016/j.scienta.2016.01.031

Kaur, G.; Asthir, B. Proline: A key player in plant abiotic stress tolerance. Biologia Plantarum, v.59, p.609-619, 2015. https://doi. org/10.1007/s10535-015-0549-3

Lacerda, C. F.; Assis Júnior, J. O.; Lemos Filho, L. C. A.; Guimarães, F. V. A.; Oliveira, T. S.; Gomes Filho, E.; Prisco, J. T.; Bezerra, M. A. Morpho-physiological responses of cowpea leaves to salt stress. Brazilian Journal of Plant Physiology, v.18, p.455-465, 2006a. https://doi.org/10.1590/S1677-04202006000400003

Lacerda, C. F.; Cambraia, J.; Cano, M. A. O.; Prisco, J. T. Proline accumulation in sorghum leaves is enhanced by salt-induced tissue dehydration. Revista Ciência Agronômica, v.37, p.110-112, 2006 b.

Lacerda, C. F.; Cambraia, J.; Cano, M. A. O.; Ruiz, H. A.; Prisco, J. T. Solute accumulation and distribution during shoot and leaf development in two sorghum genotypes under salt stress. Environmental and Experimental Botany, v.49, p.107-120, 2003. https://doi.org/10.1016/S0098-8472(02)00064-3

Li, J.; Ma, J.; Guo, H.; Zong, J.; Chen, J.; Wang, Y.; Li, D.; Li, L.; Wang, J.; Liu, J. Growth and physiological responses of two phenotypically distinct accessions of centipede grass (Eremochloa ophiuroides (Munro) Hack.) to salt stress. Plant Physiology and Biochemistry, v.126, p.1-10, 2018. https://doi.org/10.1016/j.plaphy.2018.02.018

Liu, Q.; Sun, Y.; Niu, G.; Altland, J.; Chen, L.; Jiang, L. Morphological and physiological responses of ten ornamental taxa to saline water irrigation. Hortscience, v.52, p.1816-1822, 2017. https:// doi.org/10.21273/HORTSCI12463-17

Malavolta, E; Vitti, G. C.; Oliveira, S. A. Avaliação do estado nutricional das plantas. Princípios e aplicações. 2.ed. Piracicaba: POTAFOS, 1997. 319p.

Medeiros, J. F. de. Qualidade da água de irrigação e evolução da salinidade nas propriedades assistidas pelo GAT nos Estados do RN, PB e CE. Campina Grande: UFPB, 1992. 173p. Dissertação Mestrado

Miyamoto, S.; Martinez, I.; Padilla, M.; Portillo, A.; Ornelas, D. Landscape plant lists for salt tolerance assessment. El Paso: USDI, Bureau of Reclamation, Texas Agricultural Experiment Station, 2004. 12p.

Munns, R.; Tester, M. Mechanisms of salinity tolerance. Annual Review of Plant Biology, v.59, p.651-681, 2008. https://doi. org/10.1146/annurev.arplant.59.032607.092911

Neves, A. L. R.; Lacerda, C. F. de; Oliveira, A. C. de; Sousa, C. H. C.; Oliveira, F. I. F.; Ribeiro, M. da S. S. Quantitative and qualitative responses of Catharanthus roseus to salinity and biofertilizer. Revista Brasileira de Engenharia Agrícola e Ambiental, v.22, p22-26, 2018. https://doi.org/10.1590/1807-1929/agriambi.v22n1p22-26

Niu, G.; Rodriguez, D. S.; Aguinina, L. Growth and landscape performance of ten herbaceous species in response to saline water irrigation. Journal of Environmental Horticulture, v.25, p.204-210, 2007. 
Niu, G.; Rodriguez, D. S.; McKenney, C. Response of selected wildflower species to saline water irrigation. HortScience, v.47, p.1351-1355, 2012. https://doi.org/10.21273/HORTSCI.47.9.1351

Oliveira, E. V.; Lacerda, C. F. de; Neves, A. L. R.; Gheyi, H. R.; Oliveira, D. R.; Oliveira, F. I. F. de; Viana, T. V. de A. A new method to evaluate salt tolerance of ornamental plants. Theoretical and Experimental Plant Physiology, v.30, p.173-180, 2018. https:// doi.org/10.1007/s40626-018-0112-7

Oliveira, F. I. F.; Medeiros, W. J. F. de; Lacerda, C. F. de; Neves, A. L. R.; Oliveira, D. R. Saline water irrigation managements on growth of ornamental plants. Revista Brasileira de Engenharia Agrícola e Ambiental, v.21, p.739-745, 2017. https://doi.org/10.1590/18071929/agriambi.v21n11p739-745

Rahnama, A.; James, R. A.; Poustini, K.; Munns, R. Stomatal conductance as a screen for osmotic stress tolerance in durum wheat growing in saline soil. Functional Plant Biology, v.37, p.255-269, 2010. https://doi.org/10.1071/FP09148
Seemann, J. R.; Critchley, C. Effects of salt stress on the growth, ion content, stomatal behaviour and photosynthetic capacity of a saltsensitive species, Phaseolus vulgaris L. Planta, v.164, p.151-162, 1985. https://doi.org/10.1007/BF00396077

Silva, E. N. da; Ribeiro, R. V.; Ferreira-Silva, S. L.; Viégas, R. A.; Silveira, J. A. G. Salt stress induced damages on the photosynthesis of physic nut young plants. Scientia Agricola, v.68, p.62-68, 2011. https://doi.org/10.1590/S0103-90162011000100010

Taiz, L.; Zeiger, E.; Møller, I. M.; Murphy, A. Plant physiology and development. 6.ed. Sunderland: Sinauer Associates, 2015. 761p. Toscano, S.; Trivellini, A.; Ferrante, A.; Romano, D. Physiological mechanisms for delaying the leaf yellowing of potted geranium plants. Scientia Horticulturae, v.242, p.146-154, 2018. https://doi. org/10.1016/j.scienta.2018.07.030

Wu, S.; Sun, Y.; Niu, G. Morphological and physiological responses of nine ornamental species to saline water irrigation. HortScience, v.51, p.285-290, 2016. https://doi.org/10.21273/HORTSCI.51.3.285 